\title{
Coprophilous ascomycetes in Kenya: Saccobolus species from wildlife dung
}

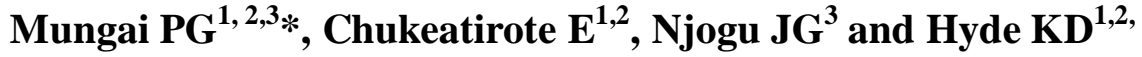 \\ ${ }^{1}$ Institute of Excellence in Fungal Research, Mae Fah Luang University, Chiang Rai 57100, Thailand \\ ${ }^{2}$ School of Science, Mae Fah Luang University, Chiang Rai 57100, Thailand \\ ${ }^{3}$ Biodiversity Research and Monitoring Division, Kenya Wildlife Service, P.O. Box 4024100100 Nairobi, Kenya
}

Mungai PG, Chukeatirote E, Njogu JG, Hyde KD 2012 - Coprophilous ascomycetes in Kenya: Saccobolus species from wildlife dung. Mycosphere 3(2), 111-129, Doi 10.5943/mycosphere/3/2/2

The taxonomy, occurrence and distribution of Saccobolus species was investigated from wild herbivore dung types in Kenya. Dung samples incubated in a moist chamber culture were examined for fungi over three months. Seven species, Saccobolus citrinus, S. depauperatus, S. diffusus, S. infestans, S. platensis, S. truncatus and S. versicolor were isolated from African elephant, black rhinoceros, Cape buffalo, dikdik, giraffe, hartebeest, hippopotamus, impala, waterbuck and zebra dung. Five taxa, S. citrinus, S. diffusus, S. infestans, S. platensis and S. truncatus, are new records for Kenya. The most common taxa were $S$. depauperatus and $S$. citrinus. The diversity of coprophilous Saccobolus species in wildlife dung is very high.

Key words - African elephant - diversity - moist chambers - national parks - Saccobolus citrinus

\section{Article Information}

Received 25 February 2012

Accepted 27 February 2012

Published online 17 March 2012

*Corresponding author: Paul G. Mungai - email - emu@kws.go.ke

\section{Introduction}

The genus Saccobolus Boud. (subfamily Ascobolideae Gray, family Ascobolaceae Sacc.) contains over 25 species (Kirk et al. 2008). The main features of this genus include apothecioid ascomata, clustered ascospores, which in most cases have brown or purplebrownish episporic pigment at maturity (van Brummelen 1967, Kaushal \& Virdi 1986, Doveri 2004, Bell 2005), with each cluster enclosed in a common gelatinous membrane. The firmly clustered bundles of ascospores are usually arranged in regular patterns (van Brummelen 1967). Saccobolus is related to Ascobolus Pers. from which it is differentiated by its clustered ascospores. Another important difference between Saccobolus and Ascobolus is the shorter but broader asci and ascospores of Saccobolus (van Brummelen 1967, Doveri 2004, Bell 2005). The apices of paraphyses usually produce a coloured pigment (van Brummelen 1967, Doveri 2004, Bell 2005).
The asci are phototropic, operculate and protrude above the hymenial surface on maturity. van Brummelen (1967) divided Saccobolus into two distinct sections, Saccobolus whose receptacles and discs are always yellow or amber with yellow or pigmented paraphyses and Eriobolus with white, pale violet, violet or brown receptacles and discs and usually colourless paraphyses. Saccobolus comprises predominantly cosmopolitan and coprophilous species (van Brummelen 1967, Doveri 2004). Numerous Saccobolus species have been recorded globally, for instance, Europe (van Brummelen 1967), Australia and New Zealand (Bell 1983, 2005), Taiwan (Wang 2000) and South America (Richardson 2008). In Africa, records of Saccobolus include, S. beckii Heimerl., S. glaber (Pers.) Lambotte, S. minimus Velen., $S$. portoricensis Seaver and $S$. verrucisporus Brumm from South Africa (Ebersohn \& Eicker 1992) while S. citrinus Boud \& 

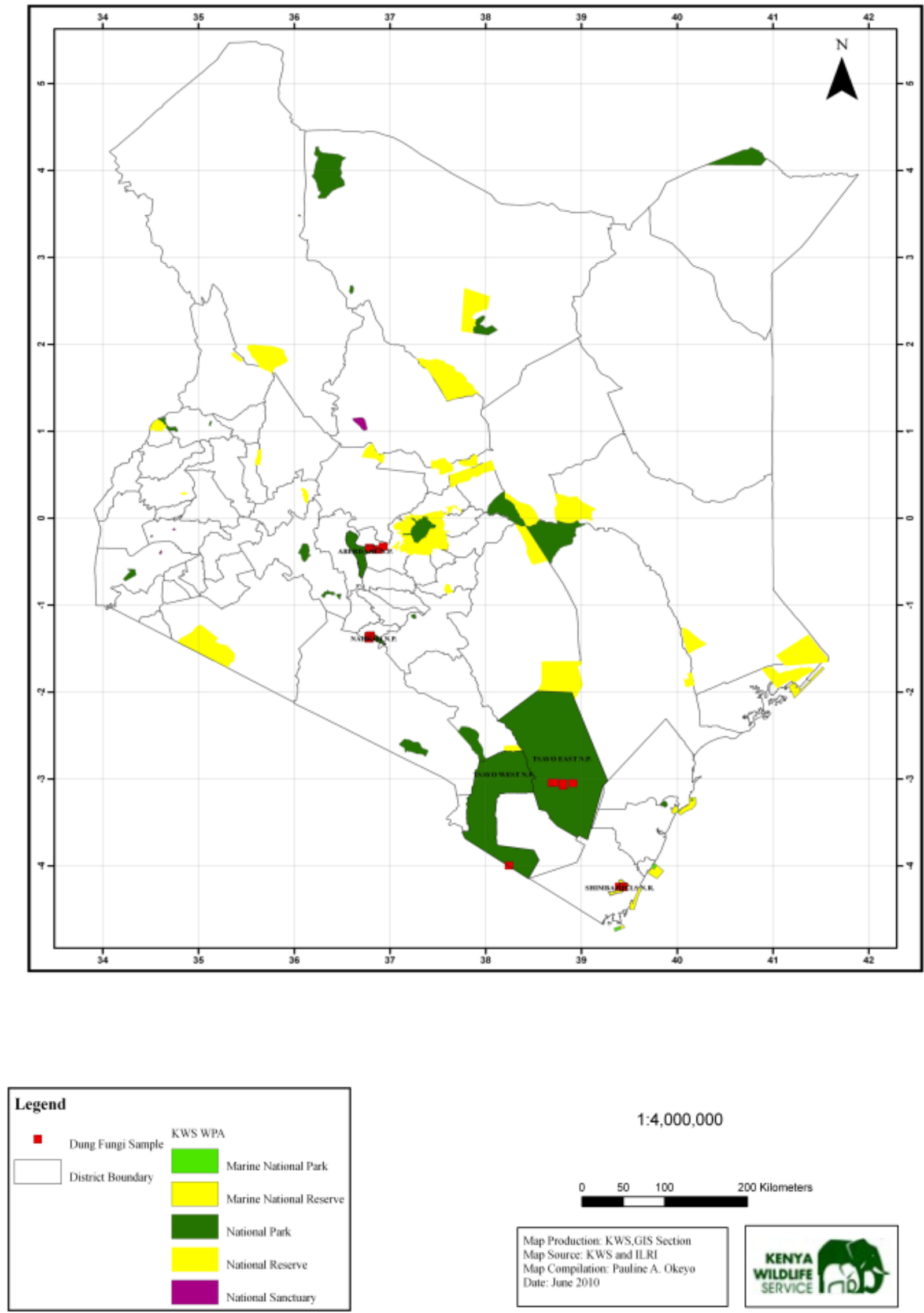

$1: 4,000,000$

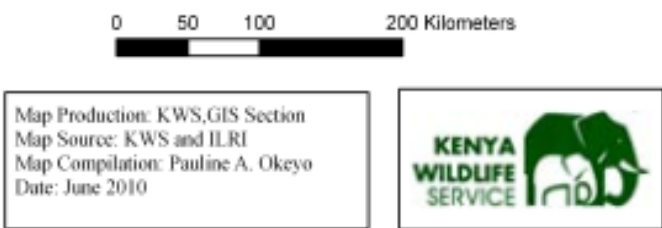

Fig 1. Map of Kenya showing wildlife dung sampling sites 
Torrend and $S$. glaber were recorded from Egypt (Abdel-Azeem et al. 2005). From Kenya Minoura (1969) and Caretta et al. (1998) recorded S. depauperatus (Berk. \& Broome) Rehm, S. versicolor (P. Karst.) P. Karst. and $S$. violascens Boud.

The objectives of the present survey were to 1) describe and classify Saccobolus species found on various dung types from Kenyan wildlife and, 2) document species diversity and distribution of Saccobolus species associated with different dung types.

In this study seven species of Saccobolus from wildlife dung are examined and illustrated.

\section{Materials and Methods}

For a detailed methodology refer to our earlier work on coprophilous Ascobolus in Kenya (Mungai et al. 2012). The sampling sites are shown in Fig. 1.

\section{Taxonomy of Saccobolus species from Kenyan wildlife dung}

Saccobolus citrinus Boud. \& Torrend, Bull. Soc. Mycol. Fr. 27: 131, 1911. (Figs.2A-I \& 3A-F)

Ascomata apothecioid, scattered or gregarious, superficial, sessile, 180-215 $\mu \mathrm{m}$ high, 205-315 $\mu \mathrm{m}$ diam. Receptacle outer surface bright to lemon yellow, smooth, without margin, subglobose, pulvinate or lenticular at maturity. Disc convex, membranaceous, lemon yellow, dotted with blackish tips of ripe protruding asci. Hypothecium and medullary excipulum not differentiated from ectal excipulum. Ectal excipulum thin composed of textura globulosa, pale yellow to yellowish grey cells, 8-20 × 8-18 $\mu \mathrm{m}$. Paraphyses cylindric-filiform, simple, septate, exceeding asci, $3 \mu \mathrm{m}$ broad, not branched, inflated tips with abundant yellow pigmentation. Asci 113-148 × 27-34 $\mu \mathrm{m}, 8$ spored, unitunicate, broadly clavate, thickwalled, flat apex, walls turning blue in Melzer's reagent; stipe short, 8-10.5 × 5.5-6 $\mu \mathrm{m}$, operculate. Ascospores 17-21 × 8-9 $\mu \mathrm{m}$, arranged according to van Brummelen pattern I, ellipsoidal-fusoid, violet to brownish purple, slightly asymetrical, with truncate or blunt ends, verruculose, sometimes with fissures, thick-walled; clusters elongated, 45-50.5 × 15$20 \mu \mathrm{m}$, compact and firmly enclosed all round in a narrow gelatinous envelope $2-4 \mu \mathrm{m}$ thick.

Material examined (4 isolates) KENYA, Nairobi National Park, Nairobi Province, GPS 37M0255729 9849626, altitude 1680m, impala dung, 20 August 2010, Paul Mungai, KWSNNP020-2010; Nairobi National Park, Nairobi Province, GPS 37M0255191 9849808, altitude $1693 \mathrm{~m}$, wooded grassland, Cape buffalo dung, 20 August 2010, Paul Mungai, KWSNNP015-2010; Nairobi National Park, Nairobi Province, GPS 37M0257082 9850692, altitude $1668 \mathrm{~m}$, wooded grassland, giraffe dung, 20 August 2010, Paul Mungai, KWSNNP017B-2010; Nairobi National Park, Nairobi Province, GPS 37M0254965 9850592, altitude $1685 \mathrm{~m}$, wooded grassland, hippopotamus dung, 20 August 2010, Paul Mungai, KWSNNP021-2010.

Notes - Saccobolus citrinus Sect. Saccobolus Boud. is similar to $S$. succineus Brumm., (van Brummelen 1969, Doveri 2004). However, it can be distinguished from these species by having lemon-yellow apothecia and notably truncate ended ascospores. In addition, the ascospores of $S$. citrinus $(21-24.5 \times 8-9.5$ $\mu \mathrm{m}$ in this examination) are narrower and more finely warted (van Brummelen 1967, Doveri 2004, Bell 2005) while those of S. succineus are larger. $S$. citrinus is quite a common species on wildlife herbivore dung in Kenya and it is a new record for Kenya.

Saccobolus depauperatus Berk. \& Broome., Ann. Mag. Nat. Hist. III 15: 448, 1865. (Figs. $4 \mathrm{~A}-\mathrm{G}, 5 \mathrm{~A}-\mathrm{C})$

Ascomata apothecioid, gregarious, superficial, sessile, 180-300 $\mu \mathrm{m}$ diam. Receptacle globose in the early stages, pulvinate to subglobose later, dirty white to pale violet, with a narrow base, smooth, margin not distinct. Disc convex, white, dotted with pale violet tips of protruding ripe asci, outer surface somewhat glabrous. Hymenium thick. Hypothecium thin, of small very compacted isodiametric cells, not well delineated. Medullary excipulum thick, made up of small textura globulosa cells. Ectal excipulum of thin, textura globulosa-angularis cells $7-11 \times$ 5.5-10 $\mu \mathrm{m}$, intercellular pigment not conspicuous amongst these cells. Paraphyses 


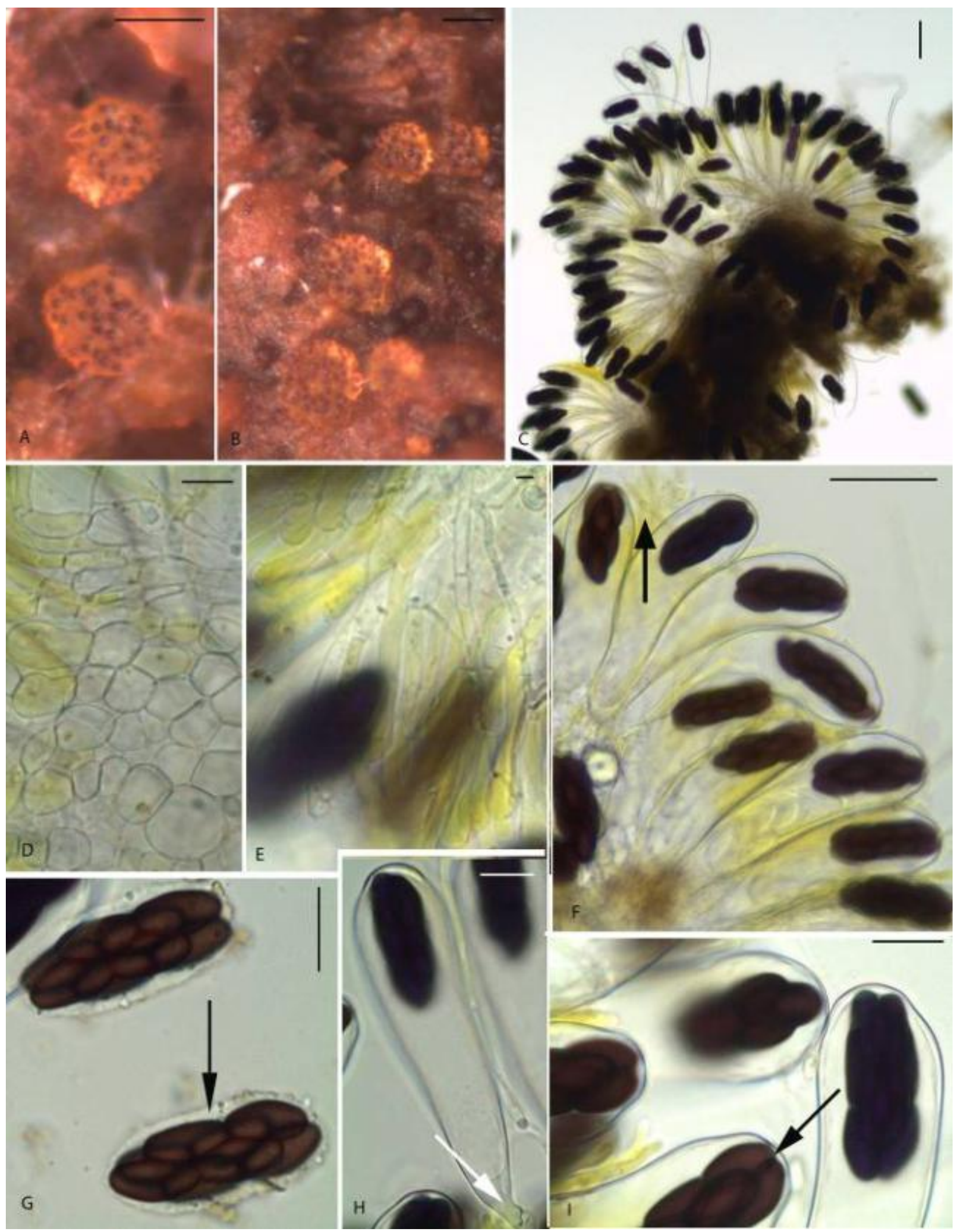

Fig. 2 - Saccobolus citrinus (KWSNNP020-2010). A-B Ascomata on dung. C Squashed ascoma. D Details of ectal excipulum near the margin. E Paraphyses filled with yellow pigment. F Mature asci and ascospores, note yellow mucus (arrow). G Mature ascospore clusters, note gelatinous sheath (arrow). H Mature ascus showing a stipe (white arrow) and an apex. I Apical portion of asci, note closed operculum (arrow). Scale bars: A-B $=500 \mu \mathrm{m}, \mathrm{C}=200 \mu \mathrm{m}, \mathrm{D}=20 \mu \mathrm{m}, \mathrm{E}=50 \mu \mathrm{m}, \mathrm{F}=20$ $\mu \mathrm{m}, \mathrm{G}=20 \mu \mathrm{m}, \mathrm{H}=20 \mu \mathrm{m}, \mathrm{I}=20 \mu \mathrm{m}, \mathrm{J}=50 \mu \mathrm{m}$. 


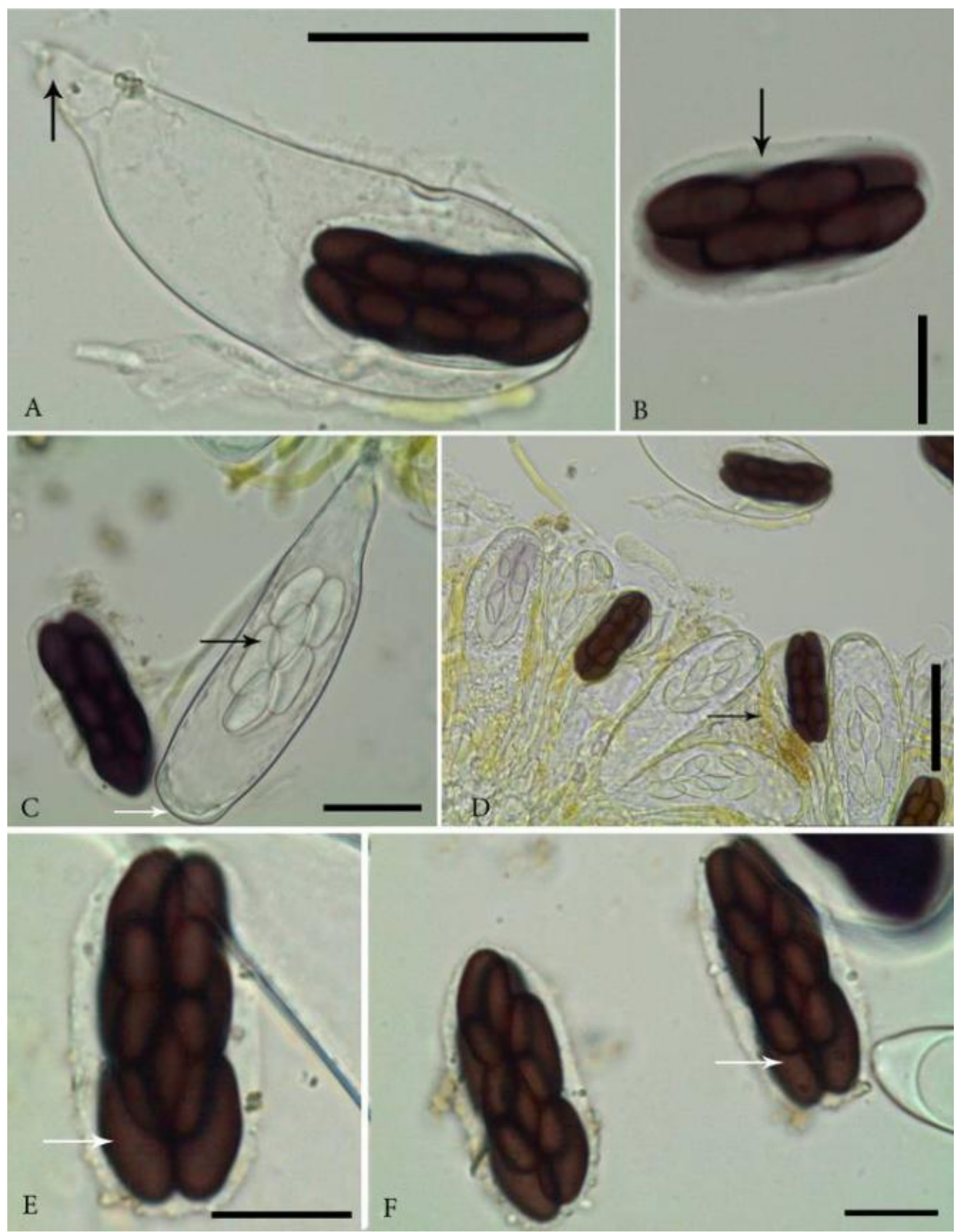

Fig. 3 - Saccobolus citrinus (KWSNNP020-2010). A Ascus, note stipe (arrow). B Ascospore cluster, note gelatinous sheath (arrow). C Free ascospore cluster and an immature ascus, note spore arrangement (black arrow), operculum, apical ring (white arrow). D-F Features of asci, ascospores and paraphyses, note yellow mucus (black arrow) and verruculose episporium (white arrows). Scale bars: $\mathrm{A}-\mathrm{D}=20 \mu \mathrm{m}, \mathrm{E}-\mathrm{F}=50 \mu \mathrm{m}$. 
cylindric-filiform, septate, exceeding the asci, width $2.5-4 \mu \mathrm{m}$, with hyaline vacuoles; tips hyaline, not inflated. Asci 62-72 × 15.5-18.5 $\mu \mathrm{m}$, 8-spored, unitunicate, claviform, often curved at apex, wall turning deep blue in Melzer's reagent, with an operculum ca.14.5 $\mu \mathrm{m}$, long stipitate. Ascospores 11.5-14 $\times$ 5-7 $\mu \mathrm{m}$, single-celled, arranged according to van Brummelen pattern II, ellipsoidal-subfusiform, somewhat asymetrical, round or truncate at the ends, purple-brown at maturity, smooth or finely dotted; clusters compact, 31.5-35 $\times$ 11.5-13.5 $\mu \mathrm{m}$, usually surrounded by a thin hyaline gelatinous sheath.

Material examined (10 isolates) KENYA, Shimba Hills National Reserve, Coast Province, GPS S04 ${ }^{\circ} 13^{\prime} 35.6^{\prime \prime}$ E039²5'31.6”, altitude 373m, giraffe dung, 26 August 2009, Paul Mungai, KWSSH0012009; Tsavo East National Park, Coast Province, GPS S03²1'06.4” E038³7'50.1”, altitude $514 \mathrm{~m}$, riverine vegetation, Cape buffalo dung, 23 August 2008, Paul Mungai, KWSTE008A-2008; Aberdare Country Club Game Sanctuary, Central Province, GPS S00 19'28.1" E03655'54.3", altitude $2161 \mathrm{~m}$, bushed grassland, zebra dung, 30 August 2009, Paul Mungai, KWSACC002-2009. Nairobi National Park, Nairobi Province, GPS S01 ${ }^{\circ} 21^{\prime} 15.1^{\prime \prime}$, E036 46'54.1', altitude 1768m, savannah grassland, impala dung, 31 August 2009, Paul Mungai, KWSNNP008-2009; Tsavo East National Park, Coast Province, GPS S03 02'29.7' E038 41'35.8”, altitude 354m, riverine vegetation, dikdik dung, 27 August 2009, Paul Mungai; KWSTE005B-2009; Aberdare Country Club Game Sanctuary, Central Province, GPS S00¹9'28.1 E036 55'54.3”, altitude 2161m, bushed grassland, giraffe dung, 30 August 2009, Paul Mungai, KWSACC003-2009; Aberdare National Park, Central Province, GPS S00²1'35.0" E03652'47.8”, altitude $2074 \mathrm{~m}$, montane forest, African elephant dung, 30 August 2009, Paul Mungai KWSANP0032009; Tsavo East National Park, Coast Province, GPS S03²1'66.6” E038³8'77.2”, altitude $514 \mathrm{~m}$, riverine vegetation, dikdik dung, 23 September 2008, P. Mungai, KWSTE005A2008; Shimba Hills National Reserve, Coast Province, GPS S04¹4'35.4” E039²6'07.2”, altitude $361 \mathrm{~m}$, hartebeest dung, 26 August
2009, Paul Mungai, KWSSH003-2009; Kinondo Forest Reserve, Coast Province, GPS S04²5'19.7' E039³2'60.2”, altitude 6m, coastal tropical rain forest, dikdik dung, 19 April 2009, P. Mungai, KWSKIN004-2009; Nairobi National Park, Nairobi Province, GPS S01 21'25.5', E036 47'51.6”, altitude 1748m, savannah grassland, giraffe dung, 31 August 2009, Paul Mungai, KWSNNP009-2009.

Notes - Saccobolus depauperatus Sect Eriobolus Sacc. is similar to $S$. versicolor (van Brummelen 1967, De Sloover 2002, Doveri 2004). The two species however have some important differences that help in their differentiation. The latter has larger apothecia, asci, single ascospores and ascospore clusters (van Brummelen 1967, Doveri 2004). The excipulum of $S$. depauperatus is usually of a textura globulosa structure unlike that of $S$. versicolor which is textura intricata (van Brummelen 1967, Doveri 2004). The apices of paraphyses and excipular cells of $S$. depauperatus are also without any pigmented intercellular mucus rendering the species to appear whitish (van Brummelen 1967, De Sloover 2002, Doveri 2004).

Saccobolus diffusus S.C. Kaushal \& Virdi, Willdenowia 16(1): 269, 1986. (Figs.6A-J, 7K$\mathrm{R})$

Ascomata apothecioid, scattered or gregarious, superficial, sessile, 220-370 $\mu \mathrm{m}$ diam. Receptacle at first subglobose to globose, obconic, finally pulvinate, greenish yellow to pale, external surface glabrous, margin entire. Hymenium convex, dotted with black tips of mature protruding ripe asci. Hypothecium thin, of small textura globulosa cells. Medullary excipulum not well delineated. Ectal excipulum of textura angularis-globulosa cells 8-10 $\times$ 4.5-8 $\mu \mathrm{m}$. Paraphyses cylindric-filiform, simple or rarely branched, septate, exceeding asci, 2.5-4 $\mu \mathrm{m}$ broad; tips with abundant greenish yellow pigmentation, not inflated. Asci 114-167 × 29-39 $\mu \mathrm{m}, 8$-spored, walls turning blue in Melzer's reagent, unitunicate, broadly clavate, tapering abruptly into a short stout and lobate stipe 13-25 × 6.5-7.5 $\mu \mathrm{m}$; apices subtruncate with an operculum 14.5-17 $\mu \mathrm{m}$ wide. Ascospores 21-24.5 × 8-9.5 $\mu \mathrm{m}$, single-celled, ellipsoidal, at first hyaline, violet to brown, smooth or verruculose, 
Mycosphere Doi 10.5943/mycosphere/3/2/2
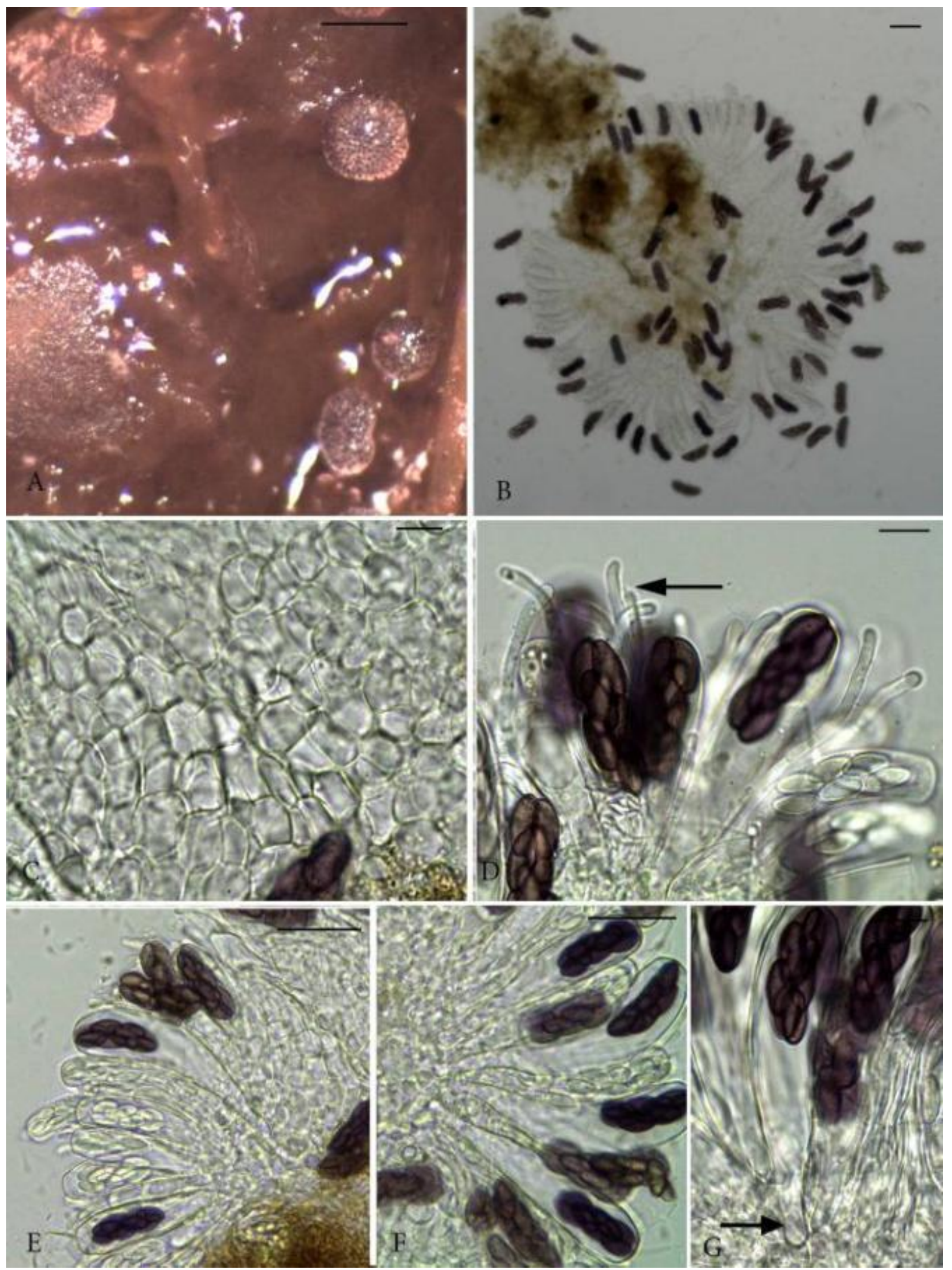

Fig. 4 - Saccobolus depauperatus (KWSSH003-2009). A Ascomata on dung. B Squashed ascoma. C Details of ectal excipulum near the margin. D Paraphyses, asci and ascospores (arrow). E-F Details of cells of the ectal excipulum seen from outside, medullary excipulum, mature and immature asci and ascospores. G Asci stipe (arrow). Scale bars: $A=500 \mu \mathrm{m}, \mathrm{B}=200 \mu \mathrm{m}, \mathrm{C}=20$ $\mu \mathrm{m}, \mathrm{D}=20 \mu \mathrm{m}, \mathrm{E}-\mathrm{F}=50 \mu \mathrm{m}, \mathrm{G}=20 \mu \mathrm{m}$. 

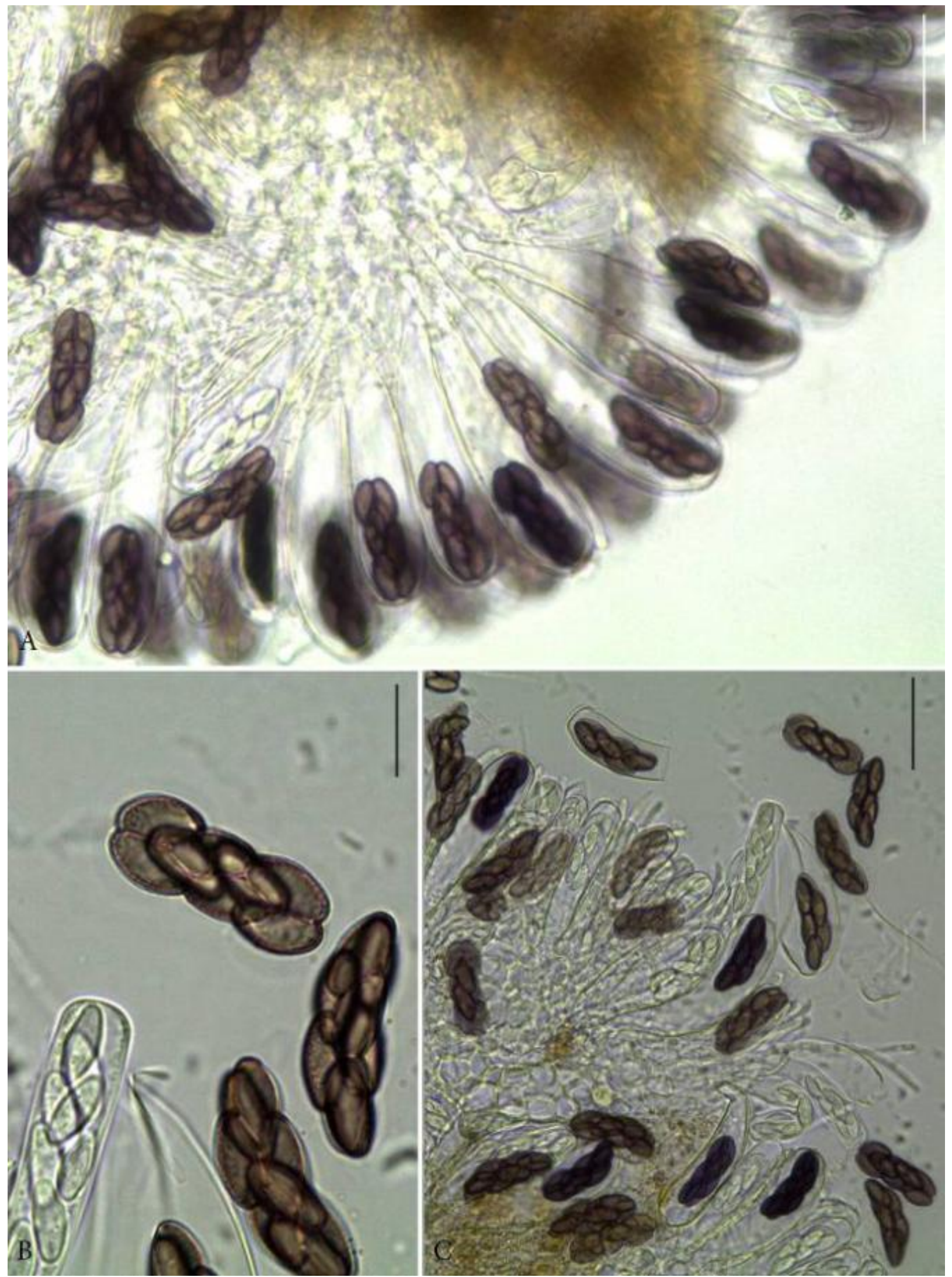

Fig. 5 - Saccobolus depauperatus (KWSSH003-2009). A Asci and ascospores. B Details of mature and immature ascospores. $\mathbf{C}$ Mature and immature asci and ascospores. Scale bars: $\mathrm{A}=50 \mu \mathrm{m}, \mathrm{B}=$ $20 \mu \mathrm{m}, \mathrm{C}=50 \mu \mathrm{m}$. 
arranged according to van Brummelen pattern I, clusters compact, 50-58 × 16-18 $\mu \mathrm{m}$, more pointed on one side, rather narrow gelatinous sheath of 2-4 $\mu \mathrm{m}$ on polar region and $4-8 \mu \mathrm{m}$ on sides.

Material examined (1 isolate) KENYA, Aberdares National Park, Central Province, GPS S00²0’23.2” E0364'11.1”, tropical montane forest, altitude $2075 \mathrm{~m}$, waterbuck dung, 72 days incubation, 29 August 2010, Paul Mungai, KWSANP005-2010.

Notes - Saccobolus diffusus Sect. Saccobolus is morphologically very similar to $S$. citrinus but the latter has smaller apothecia, smaller ascospore clusters and smaller ornamented single ascospores (Kaushal \& Virdi 1986, Doveri 2004). S. glaber, another similar species, is differentiated by having lemonyellow apothecia, larger asci $(140-275 \times 25-48$ $\mu \mathrm{m})$, larger ascospore clusters (50-68 $\times 16-25$ $\mu \mathrm{m})$, larger individual ascospores $(22-29 \times 8.5-$ $14.5(-16 \mu \mathrm{m})$ and the presence of paraphyseslike hyphae in the upper part of the excipulum (Kaushal \& Virdi 1986, Doveri 2004). This is a new record for Kenya.

Saccobolus infestans (Bat. \& Pontual) Brumm., Persoonia, Suppl. 1: 204, 1967. (Figs.8A-K) Ascomata scattered or gregarious, superficial, sessile, white, margin not differentiated, 150-350 $\mu \mathrm{m}$ diam. Ectal excipulum of textura globulosa, cells 3-3.5 $\mu \mathrm{m}$ diam. Paraphyses simple, clavate, septate, exceeding asci, 3-4 $\mu \mathrm{m}$ broad, olive or yellow pigmented, slightly curved, slightly inflated at the tips. Asci $44-59 \times 12-18 \mu \mathrm{m}, 8$-spored, unitunicate, broadly clavate, wall blueing in Melzer's reagent, operculate, with a rather short stout stipe. Ascospores 8-10 × 4.5-6 $\mu \mathrm{m}$, single-celled, ellipsoidal, with broadly rounded ends, at first hyaline, finally violet to brown, verruculose or roughened with minute dots, arranged according to various forms of pattern VI of van Brummelen; clusters compact, arranged in two rows, $19-25 \times 9.5-11.5 \mu \mathrm{m}$, cemented together by a hyaline gelatinous sheath.

Material examined (1 isolate) KENYA, Nairobi National Park, Nairobi Province, GPS 37M0257082 9850692, altitude $1668 \mathrm{~m}$, grassland, zebra dung, 59 days incubation, 20 August 2010, Paul Mungai,
KWSNNP018-2010.

Notes $-S$. infestans is a unique species owing to its characteristic ascospore arrangement. This species is not likely to be confused with other currently known Saccobolus species (van Brummelen 1967, Doveri 2004). S. infestans, observed only once in a single dung type, appears to be a rare, late sporulating coprophilous fungi species from Kenyan wildlife. This is a new record for Kenya.

Saccobolus platensis Gamundí \& Ranalli, Nova Hedwigia 17: 385, 1969. (Fig. 9A-F)

Ascomata apothecioid, gregarious, superficial, sessile, 650-750 $\mu \mathrm{m}$ diam. Receptacle pulvinate, glabrous, amber to yellow, margin not differentiated. Disc convex or flat. Hymenium dotted with far protruding, almost black tips of ripe asci. Hypothecium composed of yellow-greyish globular cells. Medullary excipulum not well differentiated from ectal excipulum. Ectal excipulum of textura globulosa cells 5-8 $\times$ 5-8 $\mu \mathrm{m}$. Paraphyses filiform, simple, septate, in yellow pigment, scanty, tips just slightly swollen, 3-4 $\mu \mathrm{m}$ diam. Asci $90-120 \times 18-23 \mu \mathrm{m}, 8$-spored, unitunicate, clavate, with a pronounced apical ring, curved, usually with a fairly long stipe. Ascospores 14-17 × 6-9 $\mu \mathrm{m}$, ellipsoidal, purple to brown at maturity, rough or with fine warts, truncate ends, symmetrical, arranged according to pattern I of van Brummelen; clusters compact, $35-41 \times 12-16 \mu \mathrm{m}$, surrounded by a hyaline, common broad gelatinous sheath.

Material examined (3 isolates) KENYA, Tsavo East National Park, Coast Province, GPS S0321'666” E038 $38^{\circ}$ '772”, altitude $514 \mathrm{~m}$, savannah grassland, 18 and 57 days incubation, elephant dung, 23 September 2008, Paul Mungai, KWSTE005A-2008; Aberdares National Park, Central Province, GPS S00²0'23.2" E036 47'11.1", tropical montane forest, altitude $2075 \mathrm{~m}$, water-buck dung, 29 August 2010, Paul Mungai, KWSANP0052010.

Notes - Saccobolus platensis is very similar to $S$. minimus from which it is differentiated by its smaller ascospores and asci, irregular and rough episporium (Richardson \& Watling 1997, Doveri 2004). The two species share a lot of similarities and 

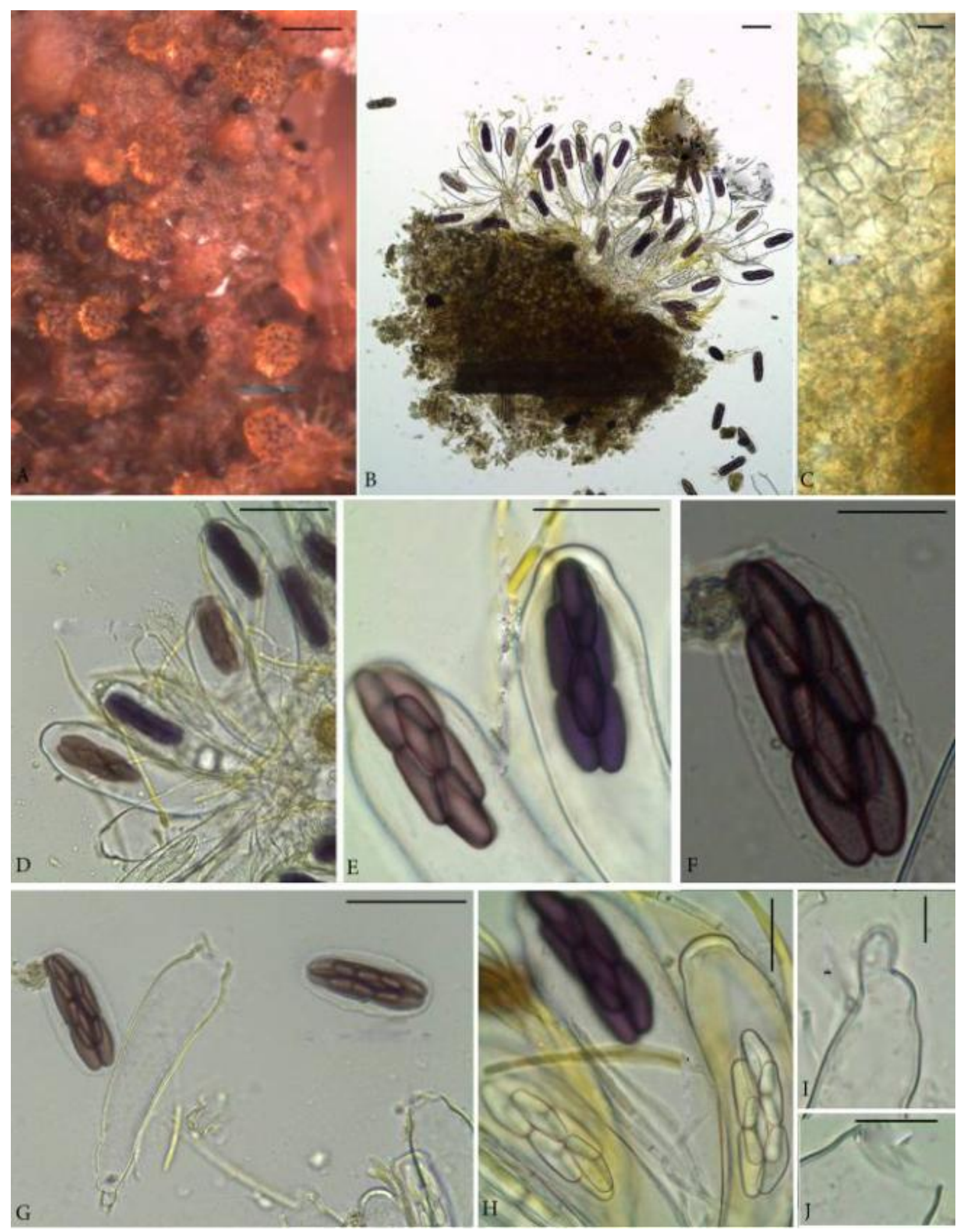

Fig. 6 - Saccobolus diffusus (KWSANP005-2009). A Ascomata on dung. B Squash ascoma. C Details of ectal excipulum. D Asci and ascospores among paraphyses. E Apical part of ascus. F Gelatinous envelope around ascospore cluster. G Free mature ascospores and a dehisced ascus. H Ascospore arrangement, paraphyses and hyaline immature spores in yellow mucus. I Ascus stipe. J Open operculum. Scale bars: $\mathrm{A}=500 \mu \mathrm{m}, \mathrm{B}=200 \mu \mathrm{m}, \mathrm{C}=20 \mu \mathrm{m}, \mathrm{D}=50 \mu \mathrm{m}, \mathrm{E}-\mathrm{F}=20 \mu \mathrm{m}$, $\mathrm{G}=50 \mu \mathrm{m}, \mathrm{H}-\mathrm{J}=20 \mu \mathrm{m}$. 

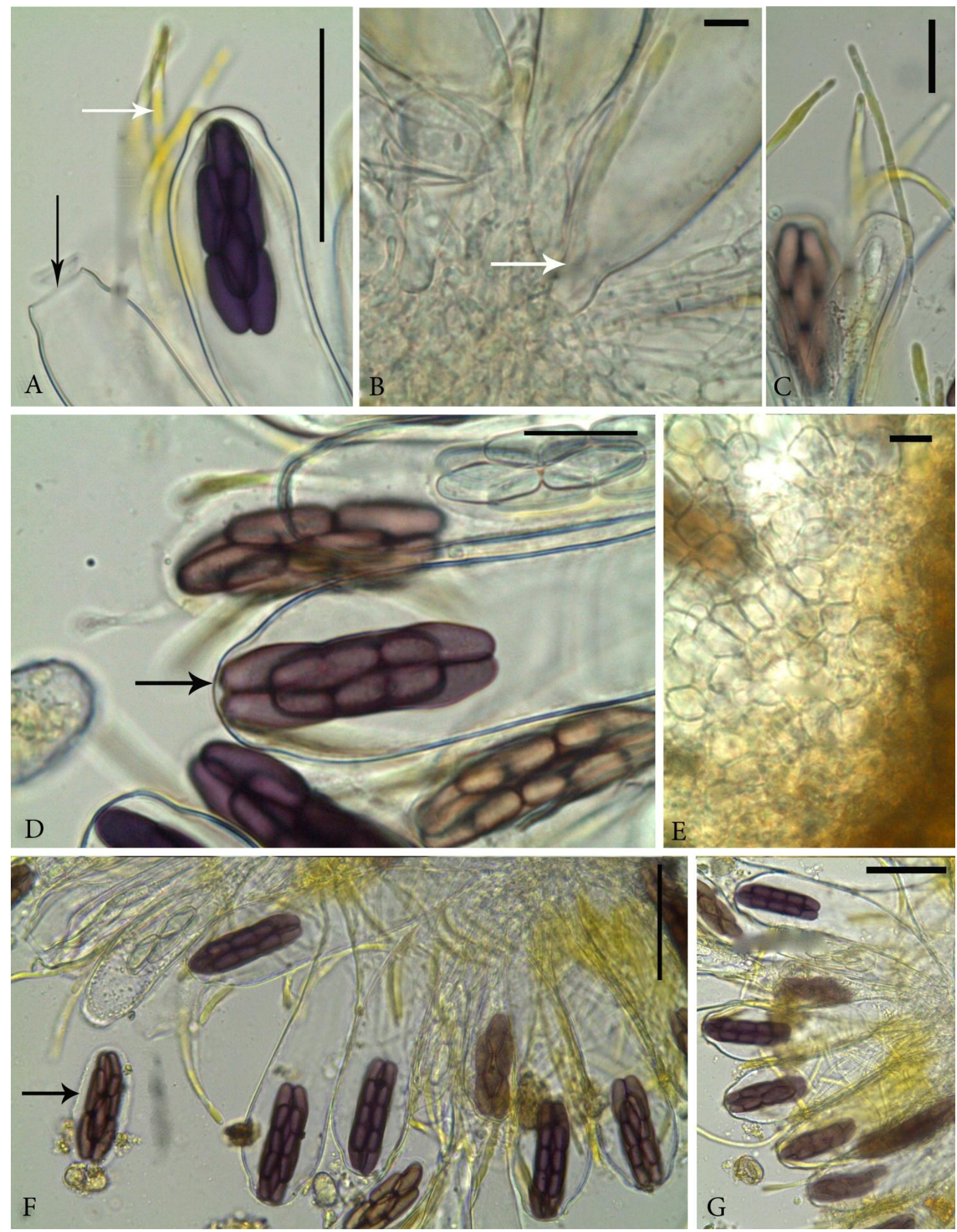

Fig. 7 - Saccobolus diffusus (KWSANP005-2010). A Asci showing open operculum (black arrow), apical portion and upper parts of paraphyses with yellow pigment (white arrow). B Ascus stipe and paraphyses, note attachment to basal cells (arrow). C Paraphyses. D Ascospores in apical portion of ascus, note closed operculum (arrow). E Cells of ectal excipulum. F-G Mature asci and ascospores, note gelatinous sheath (arrow) and the yellow pigmentation on paraphyses. Scale bars: $\mathbf{D}-\mathbf{E}=20$ $\mu \mathrm{m}, \mathbf{F}-\mathbf{G}=50 \mu \mathrm{m}$. 
hence are hardly separable. This is a new record for Kenya.

Saccobolus truncatus Vel., Monogr. Discom. Boh. 1: 370, 1934. (Figs.10A-D, 11E-I)

Ascomata apothecioid, gregarious or solitary, sessile, 300-400 $\mu \mathrm{m}$ diam. Receptacle globular or lenticular, pale yellow to brownish due to ascospore colour, smooth, inconspicuous due to solitary habit and small size, margin not differentiated. Disc convex, yellowish, roughened by the black protruding tips of ripe asci. Hymenium thick. Hypothecium and medullary excipulum not well delineated from ectal excipulum. Ectal excipulum of hyaline thin walled textura globulosa cells. Paraphyses cylindric-filiform, simple or branched, septate, exceeding the asci, 2-3 $\mu \mathrm{m}$ broad; tips slightly clavate, filled with yellow pigment. Asci 52-60.5 × 15-18 $\mu \mathrm{m} 8$-spored, unitunicate, wall turning blue in Melzer's reagent, cylindric-claviform, operculate, gradually tapering down into a stout stalk, thick walled, rounded to flattened apex. Ascospores 13-18 × 6-8 $\mu \mathrm{m}$, single-celled, ellipsoidal to fusiform, sometimes slightly assymetrical, purple to brown at maturity, finely granulate, thick walled, episporium peeling off with maturity, almost smooth, truncate ends, arranged according to pattern Ia of van Brummelen; clusters loose, 35-44 × 11.5-15 $\mu \mathrm{m}$ characteristically contracting, shortening and getting more rounded with age, with a broad hyaline gelatinous sheath.

Material examined (2 isolates) -

KENYA, Tsavo East National Park, Coast Province, GPS S0321'666” E038³8'772”, altitude $514 \mathrm{~m}, 54$ and 57 days incubation, giraffe dung, 23 August 2008, Paul Mungai, KWSTE002A-2008; Nairobi National Park, Nairobi Province, wooded grassland, GPS S01 21'15.1" E036 46'54.1", altitude 1768m, impala dung, 31 August 2009, Paul Mungai, KWSNNP008-2009.

Notes - Saccobolus truncatus Sect. Saccobolus is related to $S$. citrinus Boud. \& Torrend and $S$. minimus Velen (van Brummelen 1967, Doveri 2004). The former is differentiated from the latter by its smaller dotted ascospores and paler receptacles (van Brummelen 1967, Doveri 2004). The ascospores of $S$. truncatus contract characteris- tically at maturity (van Brummelen 1967, Doveri 2004). This is a new record for Kenya.

Saccobolus versicolor (P. Karst.) P. Karst., Acta Soc. Fauna Flora Fenn. 2(6): 123, 1885. (Figs.12A-G, 13H-L)

Ascomata apothecioid, scattered to gregarious, superficial, sessile, 100-150 $\mu \mathrm{m}$ diam. Receptacle at first subglobose, becoming pulvinate or lenticular, external surface smooth, hyaline to violaceous or whitish grey, margin not differentiated. Disc convex, dark, violet or almost black tips of ripe asci dotting the hymenium, outer surface somewhat glabrous. Hymenium rather thick. Hypothecium thin, not well delineated. Ectal excipulum usually poorly developed of textura-globulosaangularis to intricata elongated cells 9-16 $\times 3-$ $5 \mu \mathrm{m}$, with very pale yellowish intercellular pigment. Paraphyses cylindric-filiform, often branched and anastomosed, septate, exceeding the asci, 2.5-3.5 $\mu \mathrm{m}$ broad, hyaline; tips inflated, sometimes embedded in an intercellular violet pigment on the upper parts. Asci 124-146 × 30-32 $\mu \mathrm{m}, \quad 8$-spored, unitunicate, broadly clavate, truncate apex, walls turning blue in Melzer's reagent, operculate, short lobate stalk. Ascospores 15$19 \times 7-9 \mu \mathrm{m}, \quad$ single-celled, ellipsoidalfusiform with narrow ends, asymetrical, purple, violaceous, becoming blackish brown with age, smooth with minute pits, sometimes with fissures, with a very thick epispore, episporium of old ascospores peeling on squashing, exposing white-creamy under-coat, arranged according to pattern II of van Brummelen; clusters compact, $41-46 \times 15-18 \mu \mathrm{m}$ broad, enclosed by a granular unilateral gelatinous envelope.

Material examined (1 isolate) KENYA, Nairobi National Park, Nairobi Province, GPS 37M0255729 9849626, altitude $1680 \mathrm{~m}, 18$ days incubation, impala dung, 20 August 2010, Paul Mungai, KWSNNP0202010.

Notes - The Kenyan collection of Saccobolus versicolor Sect. Eriobolus is notably typical with hyaline to violaceous apothecia, asci $(124-146 \times 30-32 \mu \mathrm{m})$, ascospores $(15-18.5 \times 7-9 \mu \mathrm{m})$, pigmented purple-violet, becoming rough and brown with age; clusters $41-46 \times 15-18 \mu \mathrm{m}$ (in this 


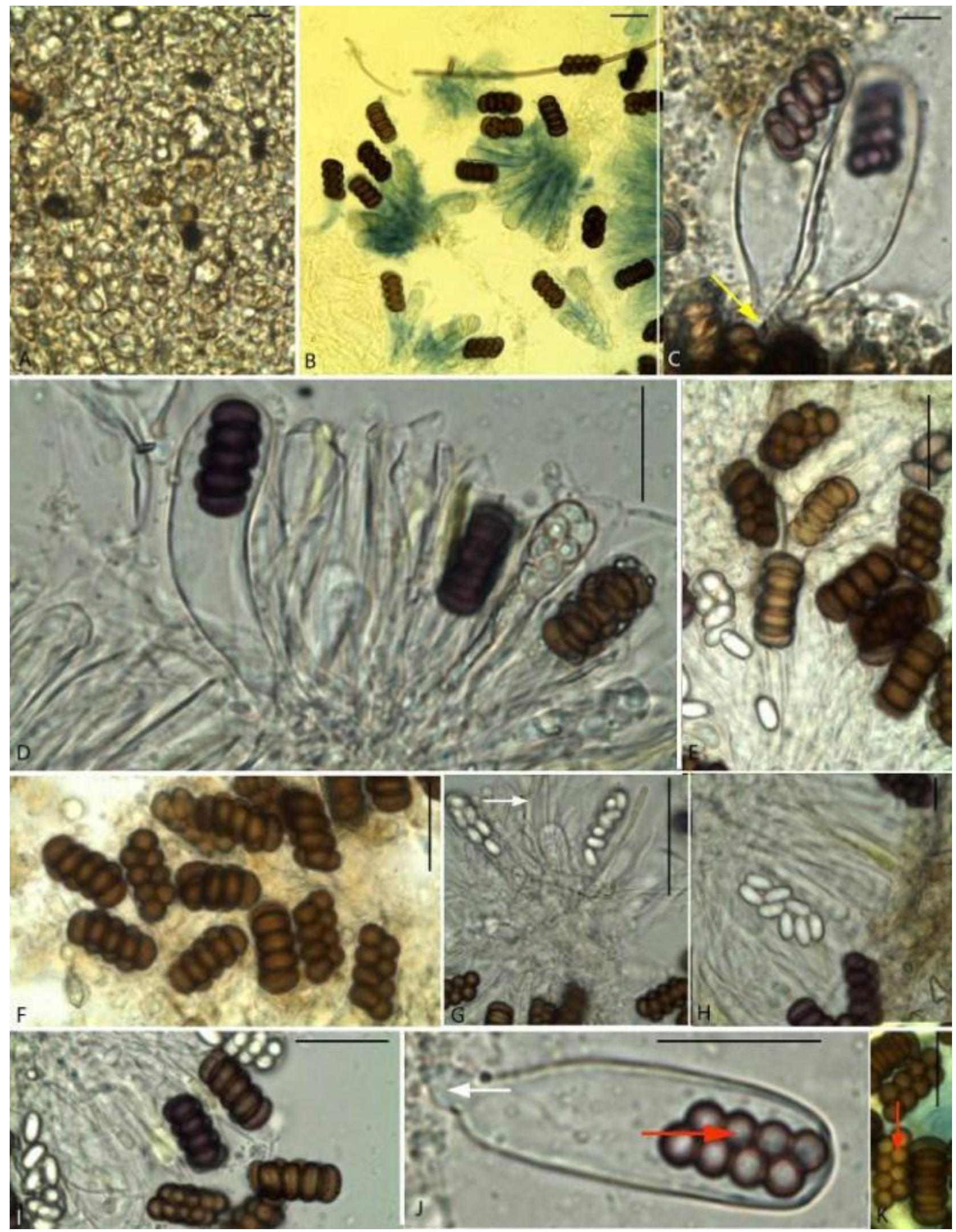

Fig. 8 - Saccobolus infestans (KWSNNP018-2009). A Details of ectal excipulum. B Mature asci and ascospores. C Mature asci showing stipe (arrow). D Mature asci with spores among dehisced asci. E-F, I Free mature ascospores. G-H Paraphyses, note colour (arrow). J Mature ascus with ascospores, showing a stipe and the spore arrangement (arrows). K Ascospores, note the arrangement (arrow). Scale bars: $\mathrm{A}=20 \mu \mathrm{m}, \mathrm{B}=50 \mu \mathrm{m}, \mathrm{C}-\mathrm{K}=20 \mu \mathrm{m}$. 

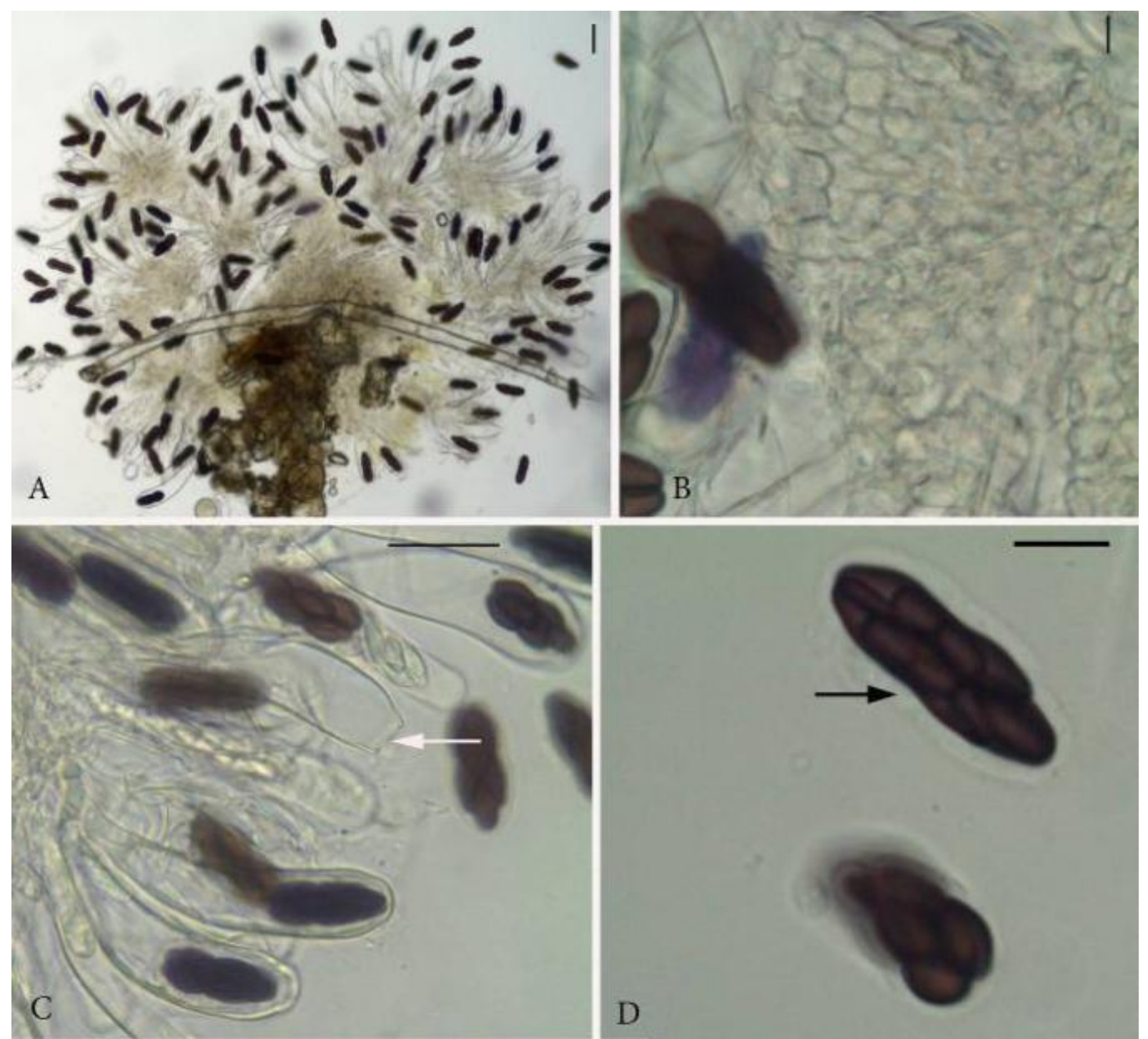

D
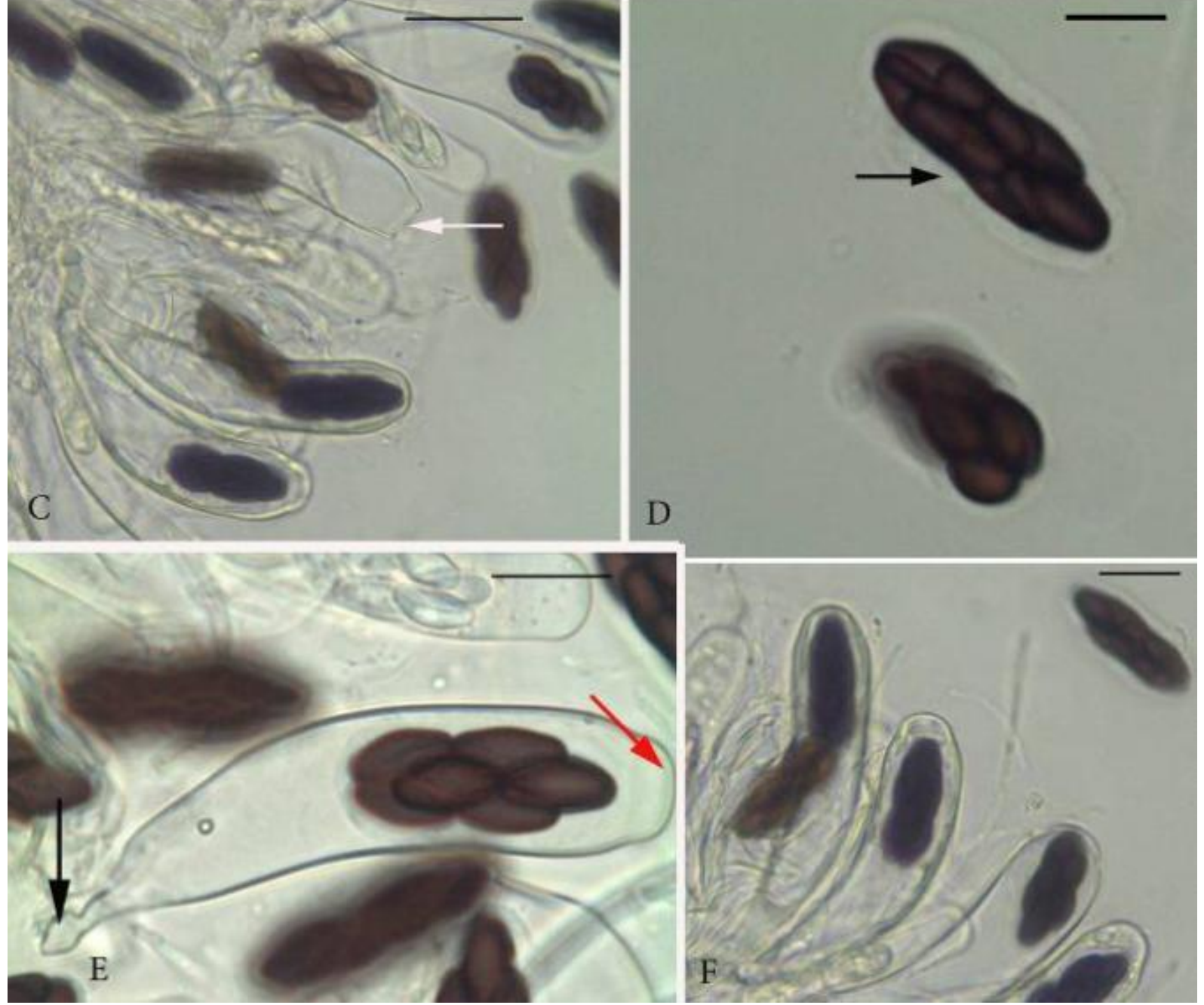

Fig. 9 - Saccobolus platensis (KWSTE005A-2008). A Squashed ascoma. B Details of ectal excipulum. C Mature asci with ascospores, note open operculum (arrow). D Ascospore showing spore arrangement and gelatinous sheath (arrow). E Ascus, note long stipe (black arrow) and closed operculum (red arrow). F Asci and paraphyses. Scale bars: A $=200 \mu \mathrm{m}, \mathrm{B}=20 \mu \mathrm{m}, \mathrm{C}=50 \mu \mathrm{m}, \mathrm{D}-\mathrm{E}$ $=20 \mu \mathrm{m}, \mathrm{F}=50 \mu \mathrm{m}$. 

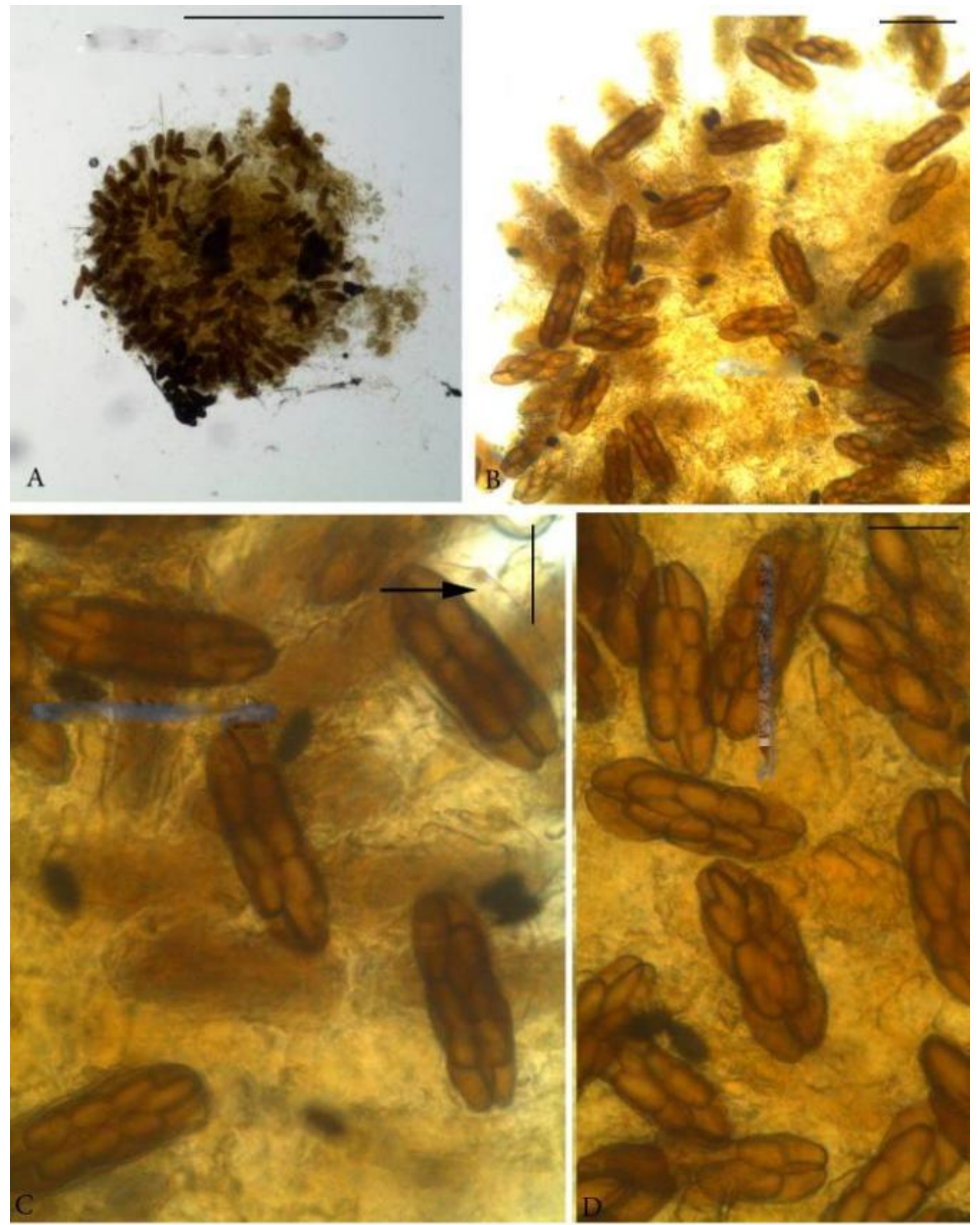

Fig. 10 - Saccobolus truncatus (KWSTE002A-2008). A Squashed ascoma. B-D Mature ascospores, note broad hyaline gelatinous envelope (arrow). Scale bars: $A=200 \mu \mathrm{m}, \mathrm{B}=50 \mu \mathrm{m}, \mathrm{C}$ $\mathrm{D}=20 \mu \mathrm{m}$.

examination). $S$. versicolor is similar to $S$. caesariatus from which it is differentiated by having hairy clusters on the external surface of its apothecia; it is also common and cosmopolitan in distribution while the latter is quite uncommon (van Brummelen 1967, Doveri 2004).

\section{Discussion}

Our specimens are typical of Saccobolus in their morphology. The diagnostic features of Saccobolus include apothecioid ascomata, always clustered ascospores which in most cases have brown or purple-brownish episporic pigment at maturity 
and with each cluster enclosed in a common gelatinous envelope (van Brummelen 1967, Doveri 2004, Bell 2005). The ascospore clusters are usually arranged in regular patterns (van Brummelen 1967). The ascus walls of Saccobolus are usually amyloid. The gelatinous sheath on ascospores were either unilateral or bilateral, that is surrounding the spores completely.
The dimensions of structures such as spores and asci are important characters when delimiting species within the genus Saccobolus. This study used morphological examinations to delimit the species.

New records for Kenya are Saccobolus citrinus, S. diffusus, S. infestans, S. platensis and $S$. truncatus.
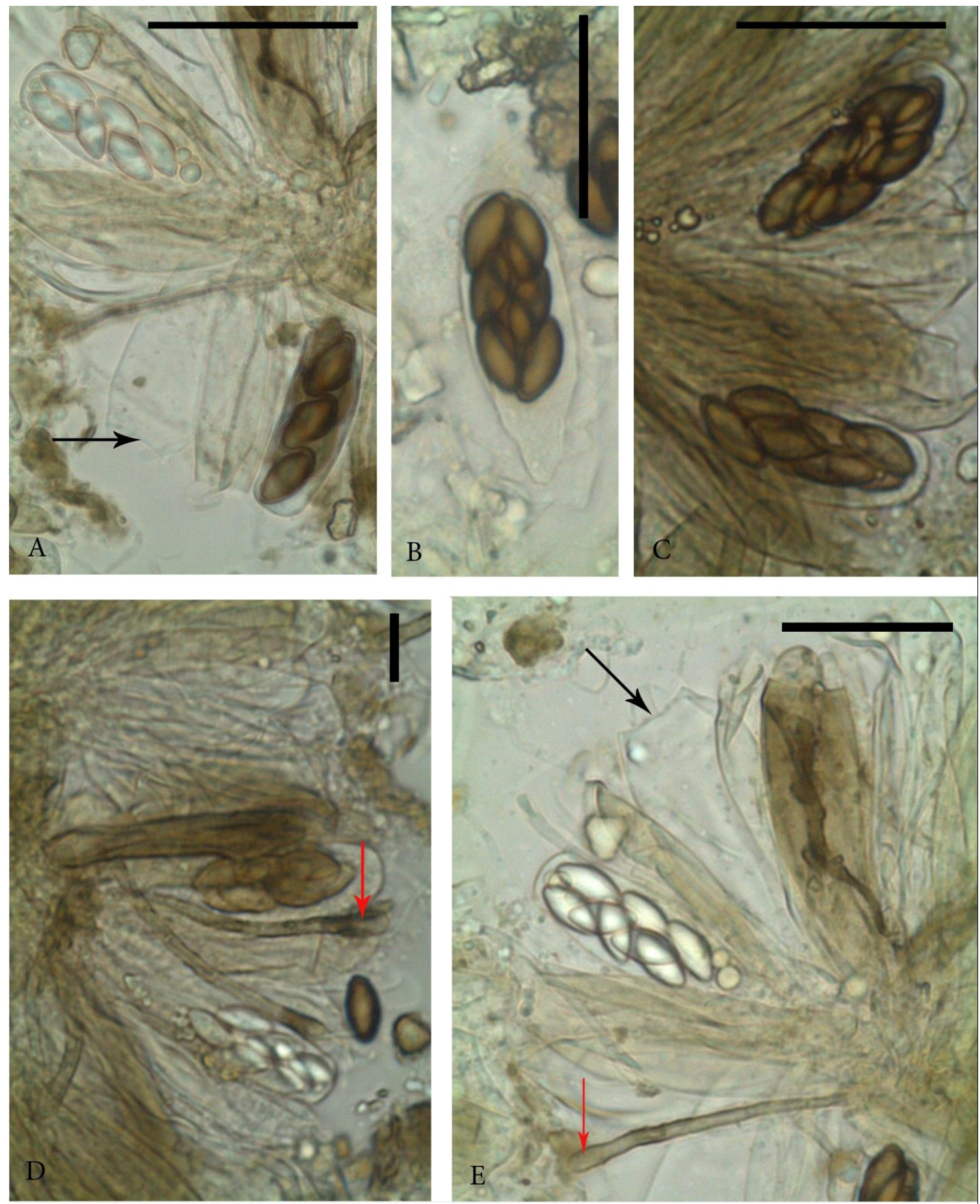

Fig. 11 - Saccobolus truncatus (KWSTE002A-2008). A-C Ascospores and asci, note open opercula (black arrow). D Asci and paraphyses. E Asci, note open opercula (black arrow), various stages of dehiscence and paraphyses tips (red arrows). Scale bars: A-E $=20 \mu \mathrm{m}$. 

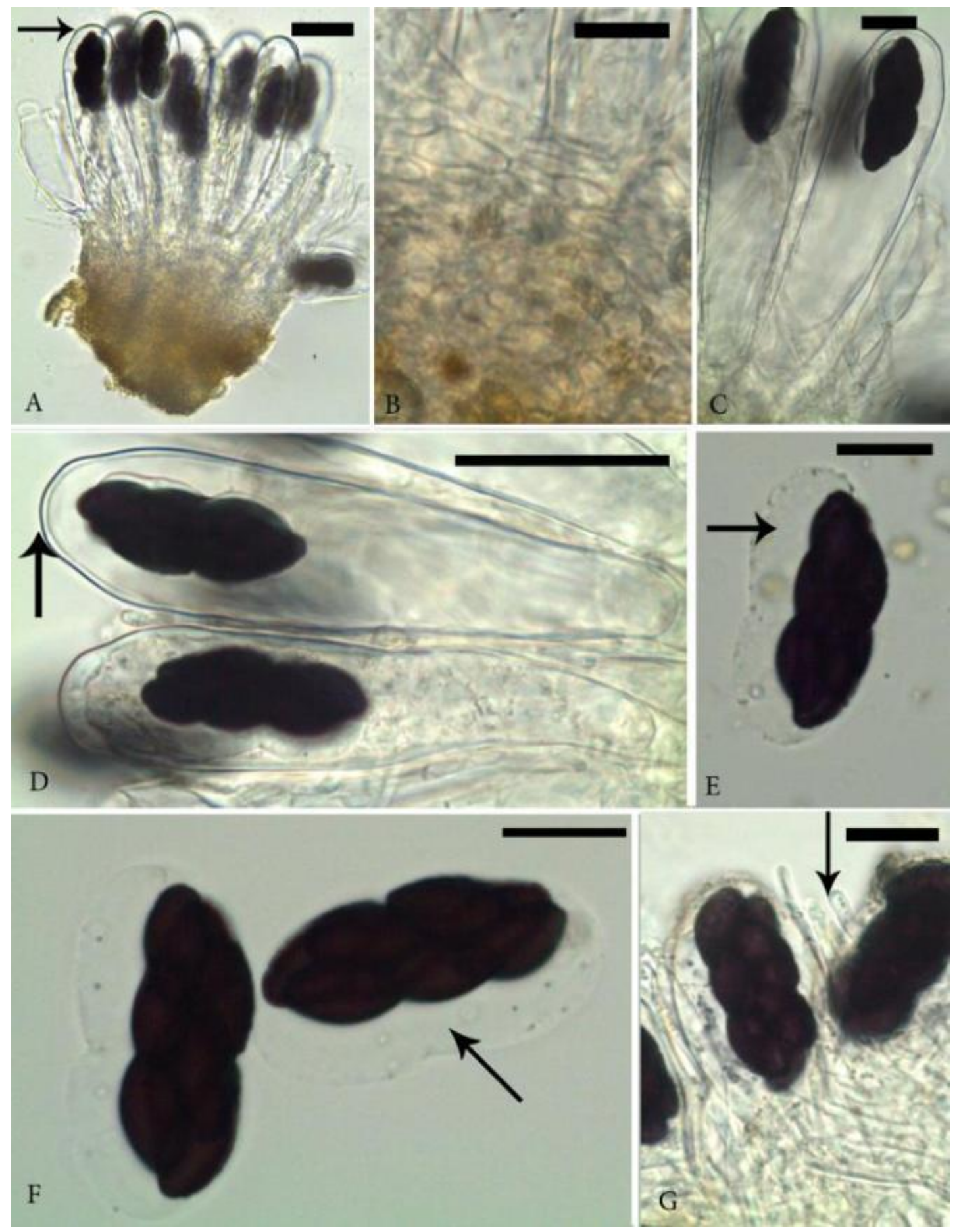

Fig. 12 - Saccobolus versicolor (KWSNNP020-2010). A Squash ascoma showing asci protruding above the hymenium (arrow). B Ascomatal wall. C-D Mature ascus and ascospores, note operculum (arrow). E-F Free mature ascospores, note gelatinous sheath (arrow). G Paraphyses and free ascospores(arrow). Scale bars: $A=50 \mu \mathrm{m}, \mathrm{B}-\mathrm{G}=20 \mu \mathrm{m}$.

\section{Ecology}

Twenty-four specimens of Saccobolus sporulated on Kenyan wildlife dung. Giraffe had 5 specimens, impala 4, waterbuck 3, African elephant 3, Cape buffalo 3, dikdik 2, zebra 2, hippopotamus 1 and hartebeest 1. Saccobolus depauperatus had the least substrate selectivity and sporulated on the most kinds of dung, while
S. diffusus and S. infestans were quite rare and were observed on a single dung type. Interestingly, giraffe and impala dung, a browser and a grazer, respectively, and hence totally different feeding habits, produced the most Saccobolus specimens.

We took note of the age of incubated dung at which Saccobolus species sporulated. 
Mycosphere Doi 10.5943/mycosphere/3/2/2/

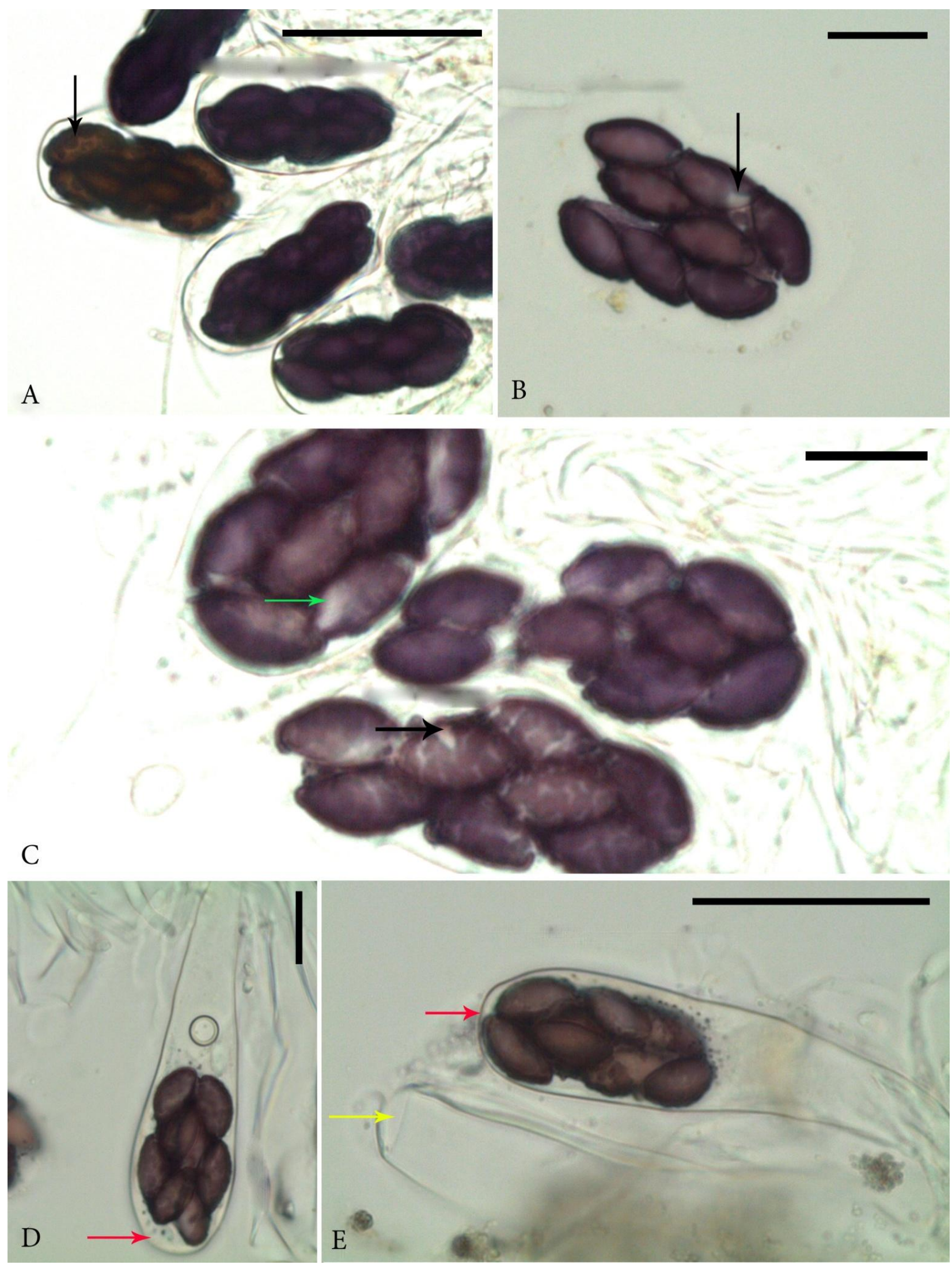

Fig. 13 - Saccobolus versicolor (KWSNNP020-2010). A Ascospores in the apical portions of asci, note a portion of thicker episporium (arrow). B-C Ascospores squashed under cover slip, note peeling episporium (arrows). D-E Mature asci with ascospores, note closed and open opercula (red and yellow arrows). Scale bars: A-E $=20 \mu \mathrm{m}$. 
Saccobolus diffusus, S. infestans, S. truncatus and S. versicolor sporulated at 40 to 70 days. S. depauperatus, the most common species, sporulated across the entire period of dung incubation. This sequential sporulation indicated a form of succession in species of Saccobolus.

Saccobolus citrinus was found only in fresh dung from wild herbivores in Nairobi National Park.

Our results show that there is high coprophilous fungi species diversity in wildlife dung. The diversity of wild animals in Kenya also implies a corresponding high dung fungi diversity. This virtually unexplored substrate may hold numerous Saccobolus species currently unknown to science with yet to be recognized useful applications.

\section{Acknowledgements}

This work was generously supported by Novozymes A/S of Denmark, Kenya Wildlife Service and the Mushroom Research Foundation. Many thanks to Dr Francesco Doveri who meticulously guided the first author in editing and in the taxonomy of coprophilous Saccobolus. It is noted that without his patience and untiring efforts this work could not have been possible. We are also indebted to all staff and students at the Institute of Excellence in Fungal Research, Mae Fah Luang University, Thailand and Kenya Wildlife Service colleagues especially Mr Moses Otiende and Dr Edward Kariuki for their interest and comments on this study. Ms Elsie Wambui Maina and Asenath Akinyi are thanked for assisting in laboratory work.

\section{References}

Abdel-Azeem AM, Kamel AK, Abo-Zied TM, Lofty EE, Mohamed ES. 2005 - Mycobiota survey of Wadi El-Arbae'en, Saint Catherine Protectorate, Egypt (Unpublished report).

Bell A. 1983 - Dung Fungi. An illustrated guide to coprophilous fungi in New Zealand. Victoria University Press, Wellington.

Bell A. 2005 - An illustrated guide to the coprophilous Ascomycetes of Australia. CBS Biodiversity Series 3.

Caretta G, Piontelli E, Savino E, Bulgheroni A. 1998 - Some coprophilous fungi from Kenya. Mycopathologia 142, 125-134.

De Sloover JR. 2002 - On four species of Saccobolus (Ascobolaceae, Pezizales) rarely collected or new to Belgium. Systematics and Geography of Plants 72, 211-224.

Doveri F. 2004 - Fungi Fimicoli Italici. Associazione Micologica Bresadola, Trento, Italy.

Ebersohn C, Eicker A. 1992 - Coprophilous fungal species composition and species diversity on various dung substrates of African game animals. Botanical Bulletin of Academia Sinica 33, 85-95.

Kaushal SC, Virdi SS. 1986 - Himalayan species of Saccobolus. A coprophilous genus of Pezizales. Willdenowia 16, 269-277.

Kirk PM, Canon PF, Stalper JA. 2008 Ainsworth and Bisby's Dictionary of the Fungi, 10th Edition. CABI Europe.

Minoura K. 1969 - Notes on some Ascomycetes of East Africa. Transactions of the Mycological Society of Japan 10, 41-46.

Mungai PG, Njogu JG, Chukeatirote E, Hyde KD. 2012 - Studies of coprophilous ascomycetes in Kenya. Ascobolus species from wildlife dung. Current Research in Applied and Environmental Mycology 2, 116.

Richardson MJ. 2008 - Records of coprophilous fungi from the Lesser Antilles and Puerto Rico. Caribbean Journal of Science 44, 206-214.

Richardson MJ, Watling R. 1997 - Key to fungi on dung. Byford WJ. (ed). Bulletin of the British Mycological Society 2, 18-46.

van Brummelen J. 1967 - A world monograph of the genera Ascobolus and Saccobolus(Ascomycetes, Pezizales). Persoonia Supplement 1, 1-260.

van Brummelen J. 1969 - Studies on Discomycetes-III. Persoonia 5, 225-231.

Wang Y-Z. 2000 - Studies on the coprophilous Ascomycetes in Taiwan. Fungal Science 15, 43-46. 